\title{
KRUKENBERG'S SPINDLE
}

\author{
BY
}

\author{
Ernest Thomson, M.D. and A. J. Ballantyne, M.D. \\ STIRLING \\ GLASGOW
}

IN view of the renewed interest in this abnormality due to the publication in this journal of articles by Cardell and by R. R. James, we think it worth while to refer to a case of congenital bilateral pigmentation of the cornea which we published in the Trans. Ophthal. Soc. U.K., 1903, and which was there stated to be a condition "apparently identical with that described by Krukenberg and by Stock." The drawing (by Ballantyne) was not published in the Trans. Ophthal. Soc. U.K., and it is mainly for that very important reason that we again present the case. In describing it we cannot do better than quote from the Transactions.

The patient was a myopic girl, aged 22 years; the corrected visual acuteness was $6 / 9$ and J1. with either eye.

"In the middle of each cornea there is a faint brown vertical line. On oblique examination, especially when assisted by magnification, it is seen that this line is composed of a great number of minute, chocolate-coloured dots. The largest and densest mass of dots is opposite the centre of the pupil. From this point downwards for a distance equal to one-fourth the corneal diameter the dots are fewer and spread out like the tail of a comet, the centre of the tail being denser than its edges. The pigment is interstitially placed, but its exact depth is difficult to determine." (At that date slit-lamp examination was not available, and our estimate of the position of the pigmentation was possibly faulty.) The history obtained from the mother was entirely negative as regards birth injury, or previous inflammation of the eyes such as might account for the condition. "No trace of iris adhesion, indicating a previous irido-keratitis, can be found. The iris is normal in every respect and there are no visible remains of a pupillary membrane. There are no vitreous opacities."

We considered that we were dealing with a congenital abnormality and gave our reasons (vide Trans. Ophthal. Soc. U.K.), but had no explanation to offer as to how it occurs. Cardell in his paper says, "Krukenberg and Stock regarded the condition as being on the posterior surface of the cornea and derived from the pigment of a persistent pupillary membrane, which, once attached to the posterior surface of the cornea, had left the indication of its attachment." He seems to imply that Krukenberg and Stock, like Vogt, consider the condition to be acquired, using the term "acquired" as indicating that it resulted from disease, rather than from a developmental anomaly, although pre-natal in origin. In 


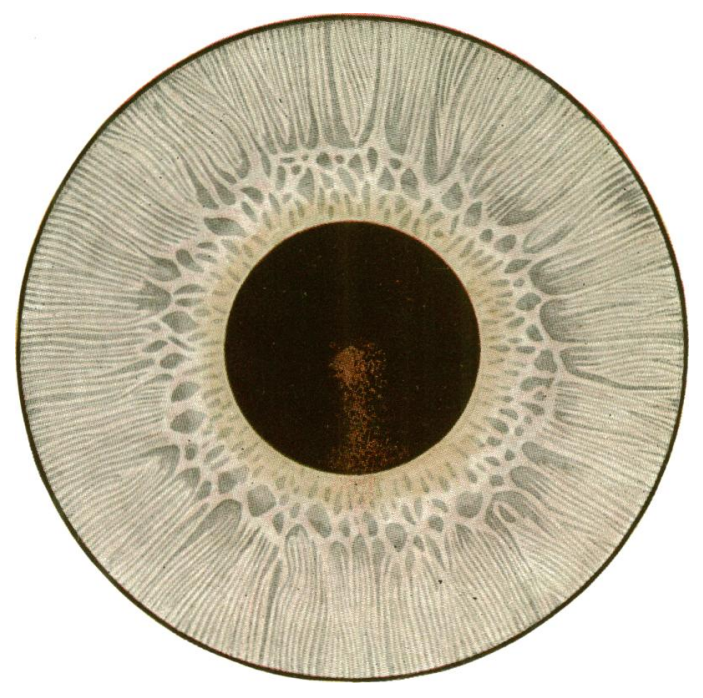

KRUKENBERG'S SPINDLE. $\quad \times 6$ diam. (A.J.B.) 
the majority of the cases referred to by Cardell the lesion was attributed to a developmental defect. Our case, in which there was no evidence of inflammation, probably belongs to this group.

\section{REFERENCES}

1. Cardell.-Brit. Jl. of Ophthal., p. 198, 1926

2. James, R. R.-Brit. Jl. of Ophthal., p. 148, 1927.

3. Krukenberg.-Klin. Monatsbl.f. Augenheilk., pp. 254, 478, 1899.

4. Stock:-Ibid., September, 1901.

5. Thomson and Ballantyne.-Trans. Ophthal. Soc. U.K., p. 274, 1903.

Note.-The recent article by Koby " Pathogénie de la pigmentation fusiforme de la face postérieure de la cornée" may be consulted with advantage. Rev. gén. d'Ophtal., February, 1927.

\section{ANNOTATION}

\section{Conservation of Vision Classes}

The American National Committee for the Prevention of Blindness has recently sent us several of their valuable reports, on some of which we have already commented. Three of these reports deal with the management and formation of special classes in ordinary schools for those children whose sight is not sufficiently defective to necessitate their treatment in special schools, but who are unable to profit sufficiently by ordinary tuition, or who are in danger of having their defect made worse by too much close work. These pamphlets are not addressed directly to ophthalmologists, although . containing much information of use to them, but to the teachers and school medical officers. Of the three pamphlets under discussion the most valuable is one by Miss Estella Lawes, which gives an account of the course of instruction given at the University of Cincinnati in 1925.

These classes are a new development in school life, and as ideas are constantly altering, it is important to remember that the subject is open to changès and improvements as fresh experience accrues. The booklet is one that should recommend itself to all ophthalmologists, and to teachers and educational boards as well. These classes are established $(a)$ to conserve sight in those children whose vision may deteriorate under ordinary school conditions; $(b)$ to afford education for children whose sight is so defective that progress is impossible without the use of large type textbooks and material; the cost of which on a large scale. is at the present time prohibitive. The children have been divided into two groups: (1) those with progressive eye defects, mainly myopes, (2) those with permanently low vision. 